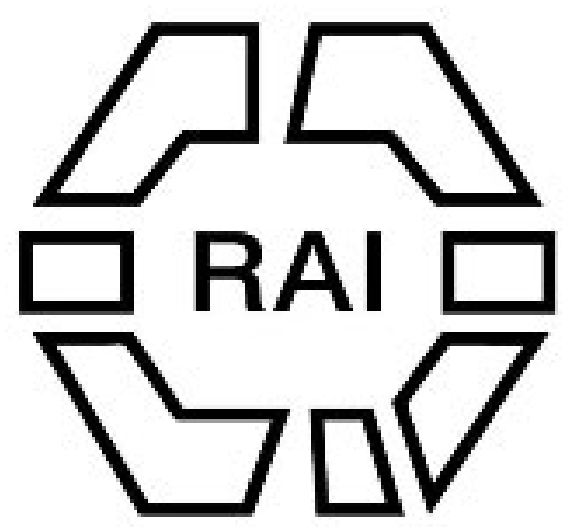

Ngala, and Its Dead Language.

Author(s): F. W. H. Migeod

Source: The Journal of the Royal Anthropological Institute of Great Britain and Ireland, Vol. 52 (Jul. - Dec., 1922), pp. 230-241

Published by: Royal Anthropological Institute of Great Britain and Ireland

Stable URL: http://www.jstor.org/stable/2843735

Accessed: 24/06/2014 23:26

Your use of the JSTOR archive indicates your acceptance of the Terms \& Conditions of Use, available at http://www.jstor.org/page/info/about/policies/terms.jsp

JSTOR is a not-for-profit service that helps scholars, researchers, and students discover, use, and build upon a wide range of content in a trusted digital archive. We use information technology and tools to increase productivity and facilitate new forms of scholarship. For more information about JSTOR, please contact support@jstor.org. 


\title{
NGALA, AND ITS DEAD LANGUAGE.
}

\author{
By F. W. H. Migeod.
}

NGALA lies about twenty-eight miles north-north-east of Dikwa on the south side of Lake Chad, from which it is distant some ten miles. The soil is all "firki," or dark grey, nearly black, clay, which is flooded in the rains, and in the dry season is cracked all over with deep fissures. Sand dunes up to about 20 feet high stand out like islands, and nearly every dune is or has been occupied by a village. It is on such an island that Ngala stands.

On the "firki" a dry-season corn called maskwa (Andropogon cernuum) is planted as soon as the water has subsided about October, the seedlings having been already started in little plots; and the crop is reaped in February and March. Wherever there is a little sandy covering to the mud, cotton is grown, and on this soil acacia trees of several varieties also flourish.

The earliest legendary record of the site is that it was inhabited by the So. The Ngala came from the east and drove them out, and they went into the lake, but the place where the refugees settled has since been covered with water. Ngala in time grew into an important place with, it is said, as many as ten thousand inhabitants. In 1900, however, Fatarella, son of Rabeh, fought against the place. It has not yet recovered, and in 1921 the population was less than nine hundred.

The Ngala claim to have migrated from Yemen in Arabia, a claim all the tribes in Bornu make. It means little more than that a few Arabs arrived with a miscellaneous following of negro slave-soldiers collected on the way, which is what Rabeh did. Nevertheless the claim points to the fact that the Chad region has from most ancient times been in communication with the upper Nile, and since the Mohammedan upheaval, if not already earlier, with Arabia. Seeing that so many tribes state they were not Mohammedan when they came, it may be assumed that many of the migrations were of people who refused to accept Mohammedanism and sought refuge in the west. If this view cannot be taken, then the migrations must be assigned to a far earlier date.

After Yemen, where the original family of Ngala was called Geirani, the next place they appear at is within measurable distance of their present town. They were at Fitri, and claim to be brothers of the Bulala. Then they moved west in stages as follows: (1) Fitri, (2) Worio, north-east of the present Fort Lamy, (3) Ngala, near Gulfei, (4) Gambaru on the Albeit river, and (5) the present Ngala, which they reached about 350 years ago. That this last estimate is not very far 
wrong is supported by the statement made to me at Mongonu, several days northwest, to the effect that when 480 years ago the So were conquered by the Sultan of Bornu, many of them fled to Ngala, which they would not have done in all probability unless it was still inhabited by their own countrymen.

The Ngala formerly had no face marks, but now cut the vertical Kanuri marks. They brought no cattle with them; and only became Mohammedan in their present locality.

Of relics of pre-Ngala days there are the huge water-pots left by the So. They are most of them broken, but many that are left still hold water in the unbroken part. They stand near the wells, and are largely used as troughs for the animals. In the rest-house compound is a complete one. It is about 4 feet high and about 3 feet in diameter. The mouth is almost the full width of the pot, and round it is only a small lip. The thickness of the sides is as' much as 2 inches. It is still perfectly sound in the at least three hundred and fiftieth year of its age. Everything the ancient So did seems to have been on a big and solid scale.

Besides pots there are found spherical stones, with two sides flattened, and about 2 inches in diameter. They are found in other ancient So towns also, but their use is not known to the Ngala. At Kaza, a neighbouring town, I was told the inhabitants now use them to plant with the corn, so as to ensure a good crop. They are then dug up and used again. Possibly the Ngala put them to the same use, but I was not so informed.

The town of Ngala is surrounded by a now very ruinous mud wall, said to have been built by Mai Bura, the first Mai, i.e. king. The houses are round, with mud walls and grass roofs, either rounded off on top or peaked. The old houses of the more important people and the Mai's house are all square shaped.

The Chief's house was practically a fort within the town wall. The bulk of it is now a heap of ruins, and inside one of the great heaps I was told there was a buried chamber, presumed to be still intact. Nevertheless there is still a habitable portion on the south side. The main gate is the principal feature. The big door opens into a small room or porch. In the almost collapsing lintel or roof is a pot with the bottom knocked out. There was formerly a room over the gateway, and there they said an old woman used to sit and watch who passed in and out of the gate. The fact of there being upper storeys indicates that the Mai of Ngala held a high rank in the old Bornu empire. The privilege of an upper storey was very restricted. Now the Mai, though of ancient lineage, is a small man. He takes his orders from a Kaigama, i.e. District Head, who is an ex-slave.

Inside the gate on the south side is a flight of some half-dozen steep steps with a mud seat at the top backing against an inner wall. Here in the old days the Mai used to sit and hear disputes.

Passing behind this, in a tiny walled yard, was a small wooden door. Inside was a small square room. Another small room leads out of it on the left, the latter 
only being lighted by a hole high up in the wall. These two cells are practically in the thickness of the outer wall, and from outside I found the light hole high up, almost at the top. At the present day they are used for storing corn, and some sitting hens were also inside. In them a century ago once lodged Shehu Lamino. It was he who, by defeating the Fulani, became the de facto ruler of Bornu ; but it remained for his son Shehu Umar to put an end to the ancient line of sultans, then become effete. It is a dynasty of Shehus that now reigns in Bornu.

These two rooms, the Mai said, had never been repaired since, and the timbers supporting the mud roof are still quite sound.

I was also shown the room of Mariam Aissa, daughter of Mai Mele, the present Mai's great- (or great-great-) grandfather. She was married to Shehu Lamino, and her father gave her for a dowry a thousand slaves, besides cattle. I asked the Mai if he could give such a dowry now. He said he wished he could. Shehu Lamino divorced Mariam Aissa later, but not till she had borne him two sons, Aba Yusuf and Abubakar, and a daughter, Nana Roiya, all of whom are said to have descendants.

The Mai's own room is circular, about 20 feet in diameter, and stands by itself. With the exception of renewing the grass roof, he said it was just as it used to be 260 years ago, when presumably it was built. It is entered from a very small courtyard after passing through two or three other yards and turning corners. Inside on the right is a large mud bed about a foot high. The Mai said he never slept there, as it was haunted. He slept on a mat on the opposite side of the room, with a skin laid on top of it. The skin was of a red hyæna of the striped variety. There was very little else inside the room but a saddle and it was evidently not swept daily. In one of the little yards was a well-grown ficus tree.

In the old days, when a Mai was elected, if he was not the eldest son of the family, his elder brother or brothers were buried alive in the walls of the palace, standing upright. An inverted pot, not very large, was shown me in one place. It was partly buried, appearing to have weathered out. They said it covered the head of one of these sacrifices. The next day I was able to confirm the accuracy of these statements, for, in examining the outer wall on the outside, I found the outline of a human skeleton and asked about it. It was in the western wall on the south side of the gate which faces west, as do the gates of all chiefs' houses in Bornu. Then more information was forthcoming. The Chief said it was the elder brother of an earlier Mai, but did not say which, who, on the election of his younger brother, had been promptly seized, bound, and buried standing up. There is a pot over his head, and also under his feet, but the distance between the two only measures about 4 feet. That this is due to the collapse or settling of the wall is probable, as the topmost bones seemed to be vertebræ. The outline of the skull I could not trace, even by scraping the surface. If the head was not buried straight away, but only covered with a pot, and then the earth put over, it would probably have bowed down 
when the victim suffocated. I rather formed the impression it was the back of the skeleton I was looking at.

Also buried in the ground on the ruined walls were many small earthenware pots full of the round stones I have mentioned above. In this connection, it must not be overlooked that in a country where there is no rock at all, any stone would be an object of curiosity to persons who had never travelled and seen a stone.

On inquiring where the Ngala kings were buried, I was first told in the bush beyond the walls, but later, perhaps because I showed no disposition to dig up everything that was shown me, a mound was pointed out opposite the gate and between that and the outer wall of the town.

Objects of interest did not end with the Mai's ruined palace. At the northern gate of the town there is a group of wells which are 11 to 12 fathoms deep. Just inside the wall in a slight hollow is a baobab tree of a diameter of about 4 feet. There are none in the surrounding country, but a few of smaller size grow in the town. My attention was drawn to this particular tree, and I was told that it had grown out of the head of a certain celebrated man named Kamata who was buried there 300 years ago. He was widely known, but not a chief, only head of a section of the town. The explanation of the tree is that no doubt someone planted a seed there unknown to the town generally.

In telling me that the outer wall was built by Mai Bura over 300 years ago, the additional statement was made that the walls were older than this baobab tree, which is interesting as a fact bearing on the rate of growth of baobab trees, to some of which most fantastic ages have been assigned.

Half a mile in an easterly direction from the wells, and over a sandy track, is a kurna tree (Zizyphus jujuba). Under this tree lies buried the body of the Bornu sultan, Dunama, who was killed here in 1817 in battle with the Bagirmi. Also buried close to the sultan, but many years later, is a well-known Mallam of Ngala, a Kanem man by origin, named Setima Momodu Pugomi. He was buried near the sultan in compliance with his dying request to his family. The kurna is said to have begun to grow after the sultan was buried there.

Other historic places shown me were the ruins of Shehu Lamino's old house, and the compound of Mariam Aissa's mother, officially called Ya (mother) Magaram (royal) Kura (great), her personal name being Palmata. She was said to be greatgreat-grandmother to the present Mai, but as her husband the Mai was said to be great-grandfather, I am not sure which it is.

In the Rest-house compound west of the town is an enamelled iron cross on a mud mound inscribed "Toole Explorer died 1824." He was an Ensign in the 89th Regiment, who came out to join the expedition of Denham, Clapperton and Oudney, and died soon after. The cross does not mark precisely the spot where he was buried, which seems to have been slightly to the north of the monument. I also saw the site of the house he died in, and which was later occupied by Barth. 
It was northerly from the Mai's palace, and close to the south wall from which the Mai's palace is not far distant. There is clear ground there now, but three young kurna trees roughly mark the place. Owing to its reduced population there is now much vacant land in the town.

The Mai, by name Mustafa, is a tall man with a high and rather narrow head, but it did not seem to me that this is a common type in Ngala. Biggish noses seem common, however. Mai Mustafa tried to give me a list of all the Mais of Ngala from the date of their first arrival. He complained that Fatarella took the list when he sacked the town. I wrote down a list from his dictation. There were twenty-one Mais before him. He had been deposed, and after six others had been tried he had quite recently been restored. Then he tried to write them down in Arabic character, but only made twenty-four in all, including himself when restored. Both lists (given below) are presumably inaccurate, because he has only four names in all the long period before Mai Mele, who gave his daughter to Shehu Lamino, which is an approximately known date, between 1809 and 1835, when he died. A reign of fifty years each to the first four Mais would be unlikely.

I think the first list is the more exact, for the following reasons. He distinctly said there were two Tahirs, whereas his own written list only contains one. Further, Mele II and Galama Ali, who have a definite note attached to them, are wanting in the list he wrote himself. Further, the recent names are incorrect or out of order. He was, therefore, more accurate when he called them out rapidly, and I took them down without a check. The labour of writing them broke the train of memory.

He himself has a son and three daughters.

The old language of Ngala was related to the Makari farther east. Only two old men and one woman are left who know it, and the Mai only knows a very few words. The present language is Kanuri. These two old men gave me the words in the attached list. Their names are Ladan Braima, aged, perhaps, 81, and Mahman Tahir, aged 73. They are cousins, and the fathers and mothers of both were pure Ngala. I worked out their ages from the statement of the elder that the younger was born eight years after him, and that he himself was born five years before Shehu Umar became sovereign of Bornu (in 1846). There is, however, a factor of doubt in this, for Shehu Umar succeeded his father Shehu Lamino as Shehu in 1835, but he was still nominally acting for the sultans, the last of whom was killed in 1846 . Both of these old men may therefore be, and probably are, eleven years older, i.e. 92 and 84 respectively (1922).

They told me that the Germans some years ago took down a vocabulary, and that there were then five men alive, including themselves, able to supply information. Whether this vocabulary is published or not I cannot say.

One last item of archæological interest I must mention in connection with Ngala. In visiting the indigo dye pits I saw in an adjoining shed the dyed garments being beaten with mallets to give them a gloss, and I was greatly surprised to see 
lying there a very large neolithic axe head, measuring some 6 by 4 inches at least. I inquired what it was for, and was shown how it was rubbed on the cloth like a flat iron to give it a final polish. This use almost throws doubt on the assumption that these larger implements of axe shape were axes at all, and it almost suggests that the flattened spherical stones may have been formerly put to a similar use and made for the purpose. Of course, it may have simply been a case of putting an unknown handy object which had been found to some use for which it was reasonably suitable. Still, against this must be set the conservatism of technical handicraftsmen who like their accustomed tools and nothing else. I regretted I was unable to make an exhaustive inquiry into the matter.

\section{APPENDIX I.}

\section{LISTS OF THE MAIS OF NGALA.}

List A, as dictated to me by Mai Mustafa.

Bura. First Mai. Built the town wall.

Tahir J.

Idirisa.

Tahir II.

Mele. Gave daughter to Shehu Lamino.

Kalagiri.

Daudu.

Moso.

Alifa

Yerima.

Ibraim

Mele II. Brother to Lamino's wife.

Galama Ali. Maternal grandfather to Mustafa.

Shehu.

Bukar.

Abdul Kadir.

Setima.

Kali.

Ali.

Umar.

Shehu. Put by Rabeh. Son of Ibraim, who was not Mai.

Mustafa. Present Mai. Deposed.

Ali.

Ngoni.

Chiroma.

Ali.

Bukar.

Malam.

Mustafa. Restored.
LIST B, as written by himself in Arabic characters in my presence.

Bura.

Tahir.

Mele.

Idirisa.

Daudu.

Kalagiri.

Yerima.

Alifa.

Bura.

Ali.

Moso.

Abdulkadir.

Setima.

Shehu.

Ali.

Umar.

Shehu.

Bukar.

Ali.

Ngoni.

Chiroma.

Malam.

Mustafa. 
APPENDIX II.

\section{NGALA LANGUAGE. ${ }^{1}$}

\section{Numerals.}

$\begin{array}{rllll}1 & \cdots & \cdots & \cdots & \cdots \\ 2 & \cdots & \cdots & \cdots & \cdots \\ 3 & \cdots & \cdots & \cdots & \cdots \\ 4 & \cdots & \cdots & \cdots & \cdots \\ 5 & \cdots & \cdots & \cdots & \cdots \\ 6 & \cdots & \cdots & \cdots & \cdots \\ 7 & \cdots & \cdots & \cdots & \cdots \\ 8 & \cdots & \cdots & \cdots & \cdots \\ 9 & \cdots & \cdots & \cdots & \cdots \\ 10 & \cdots & \cdots & \cdots & \cdots \\ 11 & \cdots & \cdots & \cdots & \cdots \\ 12 & \cdots & \cdots & \cdots & \cdots \\ 20 & \cdots & \cdots & \cdots & \cdots \\ 30 & \cdots & \cdots & \cdots & \cdots \\ 40 & \cdots & \cdots & \cdots & \cdots \\ 100 & \cdots & \cdots & \cdots & \cdots\end{array}$

$\begin{array}{lllll}\ldots & \ldots & \ldots & \ldots & \text { Tiksang. } \\ \ldots & \ldots & \ldots & \ldots & \text { Kisang. } \\ \ldots & \ldots & \ldots & \ldots & \text { Kinga. } \\ \ldots & \ldots & \ldots & \ldots & \text { Kadi. } \\ \ldots & \ldots & \ldots & \ldots & \text { Kishenshi. } \\ \ldots & \ldots & \ldots & \ldots & \text { Kingi ti kisang. } \\ \ldots & \ldots & \ldots & \ldots & \text { Tiksang ala gada. } \\ \ldots & \ldots & \ldots & \ldots & \text { Kadi kadi. } \\ \ldots & \ldots & \ldots & \ldots & \text { Ina tiksang. } \\ \ldots & \ldots & \ldots & \ldots & \text { Hakang. } \\ \ldots & \ldots & \ldots & \ldots & \text { Hakang a tiksang. } \\ \ldots & \ldots & \ldots & \ldots & \text { Hakang a kisang. } \\ \ldots & \ldots & \ldots & \ldots & \text { Hakan ti kisang. } \\ \ldots & \ldots & \ldots & \ldots & \text { Hakan ti kingu. } \\ \ldots & \ldots & \ldots & \ldots & \text { Hakan ti kadi. } \\ \ldots & \ldots & \ldots & \ldots & \text { Hakan ti hakan. } \\ & & & & \text { (Final " g " uncertain.) }\end{array}$

\section{Human Beings.}

\begin{tabular}{|c|c|c|c|c|c|c|c|c|}
\hline Man & $\ldots$ & ... & $\cdots$ & $\cdots$ & $\ldots$ & $\ldots$ & $\ldots$ & Boloswi. \\
\hline Two men & $\ldots$ & $\ldots$ & $\ldots$ & $\ldots$ & $\ldots$ & $\ldots$ & $\ldots$ & Mawo kisang. \\
\hline Old man & $\ldots$ & ... & $\ldots$ & $\ldots$ & $\ldots$ & $\ldots$ & $\ldots$ & Bolosa gilku. \\
\hline Young man & $\ldots$ & $\ldots$ & $\ldots$ & $\ldots$ & $\ldots$ & $\ldots$ & $\ldots$ & Kokonoro. \\
\hline People ... & ... & ... & $\ldots$ & $\ldots$ & $\ldots$ & $\ldots$ & ... & Moi. \\
\hline Woman & ... & ... & $\ldots$ & $\ldots$ & $\ldots$ & $\ldots$ & $\ldots$ & Kinum $^{2}$ or Ginum. \\
\hline Two women & $\ldots$ & $\ldots$ & $\ldots$ & $\ldots$ & $\ldots$ & $\ldots$ & $\ldots$ & Ginum tu kisang. \\
\hline Many women & $\ldots$ & $\ldots$ & $\ldots$ & $\ldots$ & $\ldots$ & $\ldots$ & $\ldots$ & Ginum kadagu. \\
\hline Boy & $\ldots$ & $\ldots$ & $\ldots$ & $\ldots$ & $\ldots$ & $\ldots$ & $\ldots$ & Wula. \\
\hline Girl & $\ldots$ & $\ldots$ & $\ldots$ & $\ldots$ & $\ldots$ & $\ldots$ & $\ldots$ & Muda. \\
\hline Father ... & $\ldots$ & $\ldots$ & $\ldots$ & $\ldots$ & $\ldots$ & $\ldots$ & $\ldots$ & Aba. \\
\hline Uncle $\quad .$. & $\ldots$ & $\ldots$ & $\ldots$ & $\ldots$ & $\ldots$ & $\ldots$ & $\ldots$ & Abandisa. \\
\hline Brother & ... & $\cdots$ & $\cdots$ & $\cdots$ & $\cdots$ & $\cdots$ & $\ldots$ & Katena. \\
\hline Son & $\ldots$ & $\ldots$ & $\ldots$ & $\ldots$ & $\ldots$ & $\ldots$ & $\ldots$ & Husu. \\
\hline Grandfather & $\ldots$ & $\ldots$ & $\ldots$ & $\ldots$ & $\ldots$ & $\ldots$ & $\ldots$ & Kaga (Kanuri). \\
\hline Mother's broth & & $\ldots$ & $\ldots$ & $\ldots$ & $\ldots$ & $\ldots$ & $\ldots$ & Rafa (Kanuri). \\
\hline
\end{tabular}

1 Barth's version may be found in Notes on Some Languages of the Western Sudan, by P. A. Benton.

${ }^{2}$ Pronunciation varied from Ginūm, Ginŭm to Ginem. 


$\begin{array}{lllllllll}\text { Mother ... } & \ldots & \ldots & \ldots & \ldots & \ldots & \ldots & \ldots & \text { Ya. } \\ \text { Father's sister } \ldots & \ldots & \ldots & \ldots & \ldots & \ldots & \ldots & \text { Baba. } \\ \text { Mother's sister } & & \ldots & \ldots & \ldots & \ldots & \ldots & \ldots & \text { Igina (Kanuri). } \\ \text { Sister } \ldots & \ldots & \ldots & \ldots & \ldots & \ldots & \ldots & \ldots & \text { Katena. } \\ \text { Daughter } & \ldots & \ldots & \ldots & \ldots & \ldots & \ldots & \ldots & \text { Wutu. } \\ \text { Grandmother } & \ldots & \ldots & \ldots & \ldots & \ldots & \ldots & \ldots & \text { Kaga (Kanuri) } \\ \text { King, Chief } & \ldots & \ldots & \ldots & \ldots & \ldots & \ldots & \ldots & \text { Mai (Kanuri) }\end{array}$

Antmals.

\begin{tabular}{llllllllll} 
Bird & $\ldots$ & $\ldots$ & $\ldots$ & $\ldots$ & $\ldots$ & $\ldots$ & $\ldots$ & $\ldots$ & Zeli. \\
Bull & $\ldots$ & $\ldots$ & $\ldots$ & $\ldots$ & $\ldots$ & $\ldots$ & $\ldots$ & $\ldots$ & Dungu. \\
Cattle & $\ldots$ & $\ldots$ & $\ldots$ & $\ldots$ & $\ldots$ & $\ldots$ & $\ldots$ & $\ldots$ & Sha kadagu (many). \\
Camel & $\ldots$ & $\ldots$ & $\ldots$ & $\ldots$ & $\ldots$ & $\ldots$ & $\ldots$ & $\ldots$ & Logomi. \\
Cow & $\ldots$ & $\ldots$ & $\ldots$ & $\ldots$ & $\ldots$ & $\ldots$ & $\ldots$ & $\ldots$ & Sha. \\
Dog & $\ldots$ & $\ldots$ & $\ldots$ & $\ldots$ & $\ldots$ & $\ldots$ & $\ldots$ & $\ldots$ & Kĕlĕ. \\
Dogs, two & $\ldots$ & $\ldots$ & $\ldots$ & $\ldots$ & $\ldots$ & $\ldots$ & $\ldots$ & Keleni. \\
Donkey & $\ldots$ & $\ldots$ & $\ldots$ & $\ldots$ & $\ldots$ & $\ldots$ & $\ldots$ & Galtan gida (?). \\
Elephant & $\ldots$ & $\ldots$ & $\ldots$ & $\ldots$ & $\ldots$ & $\ldots$ & $\ldots$ & Ambu. \\
Fowl & $\ldots$ & $\ldots$ & $\ldots$ & $\ldots$ & $\ldots$ & $\ldots$ & $\ldots$ & $\ldots$ & Kusku. \\
Fowls, two & $\ldots$ & $\ldots$ & $\ldots$ & $\ldots$ & $\ldots$ & $\ldots$ & $\ldots$ & Kuskunu. \\
Goat & $\ldots$ & $\ldots$ & $\ldots$ & $\ldots$ & $\ldots$ & $\ldots$ & $\ldots$ & $\ldots$ & Mfu. \\
Fish & $\ldots$ & $\ldots$ & $\ldots$ & $\ldots$ & $\ldots$ & $\ldots$ & $\ldots$ & $\ldots$ & Chi. \\
Hippopotamus & $\ldots$ & $\ldots$ & $\ldots$ & $\ldots$ & $\ldots$ & $\ldots$ & $\ldots$ & Nai. \\
Horse & $\ldots$ & $\ldots$ & $\ldots$ & $\ldots$ & $\ldots$ & $\ldots$ & $\ldots$ & $\ldots$ & Boskom. \\
\multicolumn{1}{l}{ female } & $\ldots$ & $\ldots$ & $\ldots$ & $\ldots$ & $\ldots$ & $\ldots$ & $\ldots$ & Boskom ginem. \\
Iguana & $\ldots$ & $\ldots$ & $\ldots$ & $\ldots$ & $\ldots$ & $\ldots$ & $\ldots$ & $\ldots$ & Legu. \\
Hyæna & & $\ldots$ & $\ldots$ & $\ldots$ & $\ldots$ & $\ldots$ & $\ldots$ & $\ldots$ & Mali. \\
Jackal & $\ldots$ & $\ldots$ & $\ldots$ & $\ldots$ & $\ldots$ & $\ldots$ & $\ldots$ & $\ldots$ & Kele di lala = dog of bush. \\
Leopard... & $\ldots$ & $\ldots$ & $\ldots$ & $\ldots$ & $\ldots$ & $\ldots$ & $\ldots$ & Riga. \\
Lion & $\ldots$ & $\ldots$ & $\ldots$ & $\ldots$ & $\ldots$ & $\ldots$ & $\ldots$ & $\ldots$ & Albani. \\
Monkey & $\ldots$ & $\ldots$ & $\ldots$ & $\ldots$ & $\ldots$ & $\ldots$ & $\ldots$ & Agobali. \\
Sheep & $\ldots$ & $\ldots$ & $\ldots$ & $\ldots$ & $\ldots$ & $\ldots$ & $\ldots$ & $\ldots$ & Tumu. \\
Snake & $\ldots$ & $\ldots$ & $\ldots$ & $\ldots$ & $\ldots$ & $\ldots$ & $\ldots$ & $\ldots$ & Sengu.
\end{tabular}

Parts of the Body.

$\begin{array}{llllllllll}\text { Head } & \ldots & \ldots & \ldots & \ldots & \ldots & \ldots & \ldots & \ldots & \text { Ka. } \\ \text { Eye } & \ldots & \ldots & \ldots & \ldots & \ldots & \ldots & \ldots & \ldots & \text { Shishi. } \\ \text { Ear } & \ldots & \ldots & \ldots & \ldots & \ldots & \ldots & \ldots & \ldots & \text { Tim. } \\ \text { Nose } & \ldots & \ldots & \ldots & \ldots & \ldots & \ldots & \ldots & \ldots & \text { Ghoson, } \\ \text { Mouth } & \ldots & \ldots & \ldots & \ldots & \ldots & \ldots & \ldots & \ldots & \text { Yi. } \\ \text { Tongue } & \ldots & \ldots & \ldots & \ldots & \ldots & \ldots & \ldots & \ldots & \text { Yese. } \\ \text { Hair of head } & \ldots & \ldots & \ldots & \ldots & \ldots & \ldots & \ldots & \text { Miziga. } \\ \text { Beard } & \ldots & \ldots & \ldots & \ldots & \ldots & \ldots & \ldots & \ldots & \text { Kūm. } \\ \text { Teeth } & \ldots & \ldots & \ldots & \ldots & \ldots & \ldots & \ldots & \ldots & \text { Sinsi. } \\ \text { Arm, upper } & \ldots & \ldots & \ldots & \ldots & \ldots & \ldots & \ldots & \text { Se (?). } \\ \text { ro lower } & \ldots & \ldots & \ldots & \ldots & \ldots & \ldots & \ldots & \text { Katagellum. } \\ \text { Hand } & \ldots & \ldots & \ldots & \ldots & \ldots & \ldots & \ldots & \ldots & \text { Se. } \\ \text { Heart } & \ldots & \ldots & \ldots & \ldots & \ldots & \ldots & \ldots & \ldots & \text { Wulei. } \\ \text { Neck } & \ldots & \ldots & \ldots & \ldots & \ldots & \ldots & \ldots & \ldots & \text { We. } \\ \text { Leg, lower } & \ldots & \ldots & \ldots & \ldots & \ldots & \ldots & \ldots & \text { Sigŭl (Kanuri). }\end{array}$


Heaventy Bodies, Etc.

$\begin{array}{llllllllll}\text { Sun } & \ldots & \ldots & \ldots & \ldots & \ldots & \ldots & \ldots & \ldots & \text { Su. } \\ \text { Moon, } & & \ldots & \ldots & \ldots & & & \\ \text { Star } & \ldots & \ldots & \ldots & \ldots & \ldots & \ldots & \ldots & \ldots & \text { Cha }(?) . \\ \text { Sky } & \ldots & \ldots & \ldots & \ldots & \ldots & \ldots & \ldots & \ldots & \text { Rho. } \\ \text { Fire } & \ldots & \ldots & \ldots & \ldots & \ldots & \ldots & \ldots & \ldots & \text { Fu. } \\ \text { Water } & \ldots & \ldots & \ldots & \ldots & \ldots & \ldots & \ldots & \ldots & \text { Am, ŭm. } \\ \text { Rain } & \ldots & \ldots & \ldots & \ldots & \ldots & \ldots & \ldots & \ldots & \text { Am. } \\ \text { Wind } & \ldots & \ldots & \ldots & \ldots & \ldots & \ldots & \ldots & \ldots & \text { Shi. }\end{array}$

\section{Terrestrial ObJects.}

Flat country (firki)

Road

$\begin{array}{lllll}\ldots & \ldots & \ldots & \ldots & \text { Lala. } \\ \ldots & \ldots & \ldots & \ldots & \text { Tŭm. } \\ \ldots & \ldots & \ldots & \ldots & \text { Ngũl. } \\ \ldots & \ldots & \ldots & \ldots & \text { Kalasa. } \\ \ldots & \ldots & \ldots & \ldots & \text { Sugu. } \\ \ldots & \ldots & \ldots & \ldots & \text { Wadagei. } \\ \ldots & \ldots & \ldots & \ldots & \text { Wadagei kisang. }\end{array}$

Food.

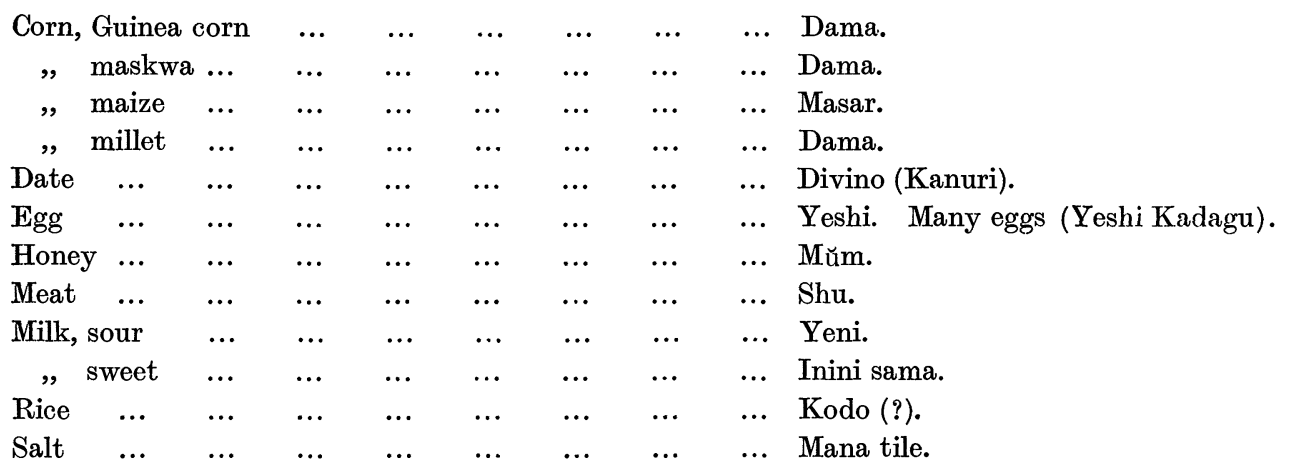

\section{Personal Atritie.}

Cloth

$\begin{array}{llllll} & \ldots & \ldots & \ldots & \ldots & \text { Luku. }\end{array}$

\section{Miscellaneous Nouns.}

\begin{tabular}{|c|c|c|c|c|c|c|c|c|c|}
\hline Arrow & $\ldots$ & $\ldots$ & $\ldots$ & $\cdots$ & $\cdots$ & $\ldots$ & $\ldots$ & $\ldots$ & Daggi. \\
\hline Bow & $\ldots$ & $\ldots$ & $\ldots$ & $\ldots$ & $\ldots$ & $\ldots$ & $\ldots$ & $\ldots$ & Zoni daggi. \\
\hline Boat & $\ldots$ & $\ldots$ & $\ldots$ & $\ldots$ & $\ldots$ & $\ldots$ & $\ldots$ & $\ldots$ & Wam. \\
\hline Box & $\ldots$ & $\ldots$ & $\ldots$ & $\ldots$ & $\ldots$ & $\ldots$ & $\ldots$ & $\ldots$ & Sandugu. \\
\hline Clay pc & $t(\operatorname{coo}$ & king) & $\ldots$ & $\ldots$ & $\ldots$ & $\ldots$ & $\ldots$ & $\ldots$ & Suga. \\
\hline Cotton & $\ldots$ & $\ldots$ & $\ldots$ & $\ldots$ & $\ldots$ & $\ldots$ & $\ldots$ & $\ldots$ & Garbun. \\
\hline House & $\ldots$ & $\ldots$ & $\ldots$ & $\ldots$ & $\ldots$ & $\ldots$ & $\ldots$ & $\ldots$ & Ra. \\
\hline " & one $r$ & om & $\ldots$ & $\ldots$ & $\ldots$ & $\ldots$ & $\ldots$ & $\ldots$ & Fŭn. \\
\hline Knife & $\cdots$ & $\cdots$ & $\ldots$ & $\ldots$ & $\cdots$ & $\ldots$ & $\ldots$ & $\ldots$ & Chunku. \\
\hline Mat & $\ldots$ & $\ldots$ & $\ldots$ & $\ldots$ & $\ldots$ & $\ldots$ & $\ldots$ & $\ldots$ & Manenaka. \\
\hline Paper, & book & $\ldots$ & $\ldots$ & $\ldots$ & $\ldots$ & $\ldots$ & $\ldots$ & $\ldots$ & Misiri. \\
\hline Spear & $\ldots$ & $\ldots$ & $\ldots$ & $\ldots$ & $\ldots$ & $\ldots$ & $\ldots$ & $\ldots$ & Alagaí. \\
\hline Stick & $\ldots$ & $\ldots$ & $\ldots$ & $\cdots$ & $\ldots$ & $\ldots$ & $\ldots$ & $\ldots$ & Zọ. \\
\hline Koran & $\ldots$ & $\ldots$ & $\ldots$ & $\ldots$ & $\ldots$ & $\ldots$ & $\ldots$ & $\ldots$ & Baga nasu. \\
\hline
\end{tabular}




\begin{tabular}{|c|c|c|c|c|c|c|c|c|c|}
\hline \multirow[b]{2}{*}{ Big } & \multicolumn{9}{|c|}{ Adjectives. } \\
\hline & $\cdots$ & $\cdots$ & $\cdots$ & $\cdots$ & $\cdots$ & $\cdots$ & $\cdots$ & $\cdots$ & Dima. \\
\hline Far & $\ldots$ & $\ldots$ & $\ldots$ & $\ldots$ & $\ldots$ & $\cdots$ & $\ldots$ & $\ldots$ & Zigili. \\
\hline Many & $\ldots$ & $\ldots$ & $\ldots$ & $\cdots$ & $\cdots$ & $\cdots$ & $\cdots$ & $\ldots$ & Kadagu. \\
\hline Red & $\cdots$ & $\cdots$ & $\cdots$ & $\cdots$ & $\cdots$ & $\cdots$ & $\ldots$ & $\ldots$ & Baya. \\
\hline Small & $\cdots$ & $\cdots$ & $\cdots$ & $\cdots$ & $\cdots$ & $\cdots$ & $\ldots$ & $\ldots$ & Cha. \\
\hline Strong & $\ldots$ & $\cdots$ & $\cdots$ & $\cdots$ & $\cdots$ & $\ldots$ & $\ldots$ & $\cdots$ & Gageru, Kakaga, Kakagaseng. \\
\hline White & $\ldots$ & $\ldots$ & $\ldots$ & $\ldots$ & $\ldots$ & $\ldots$ & $\ldots$ & $\ldots$ & Guba. \\
\hline
\end{tabular}

Cardinal Points.

$\begin{array}{llllllllll}\text { North } & \ldots & \ldots & \ldots & \ldots & \ldots & \ldots & \ldots & \ldots & \text { Yala (Kanuri). } \\ \text { East } & \ldots & \ldots & \ldots & \ldots & \ldots & \ldots & \ldots & \ldots & \text { Gedi }(\mathrm{K}) . \\ \text { South } & \ldots & \ldots & \ldots & \ldots & \ldots & \ldots & \ldots & \ldots & \text { Anum }(\mathrm{K}) . \\ \text { West } & \ldots & \ldots & \ldots & \ldots & \ldots & \ldots & \ldots & \ldots & \text { Pote }(\mathrm{K}) .\end{array}$

\section{Expreassions of Time.}

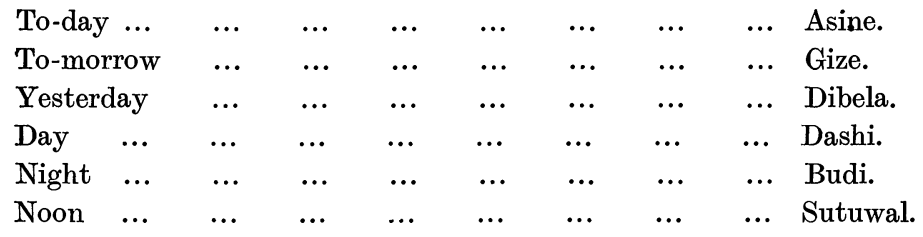

\section{VERB "To COME."}

Come here

Do not come $\quad \cdots \quad \cdots$

Whence do you come ?

I come ...

He will not come to-morrow.

He came yesterday

He did not come yesterday

The woman came yesterday

The men came yesterday
He will come to-morrow

$$
\begin{array}{lllll}
\ldots & \ldots & \ldots & \ldots & \text { Lo ngatagu. } \\
\ldots & \ldots & \ldots & \ldots & \text { Wa di ka lua (=lowa). } \\
\ldots & \ldots & \ldots & \ldots & \text { Ka lo an gate. } \\
\ldots & \ldots & \ldots & \ldots & \text { Wa lo. } \\
\ldots & \ldots & \ldots & \ldots & \text { Gize a no lo. } \\
\ldots & \ldots & \ldots & \ldots & \text { Gize no ló wa. } \\
\ldots & \ldots & \ldots & \ldots & \text { Dibela na lo. } \\
\ldots & \ldots & \ldots & \ldots & \text { Dibela na ló wa. } \\
\ldots & \ldots & \ldots & \ldots & \text { Ginum dibela na lo. } \\
\ldots & \ldots & \ldots & \ldots & \text { Dibela moi ya lo. } \\
& & & &
\end{array}
$$

Go

$\ldots \quad \ldots \quad \ldots \quad \ldots \quad \ldots \quad$ Dili.

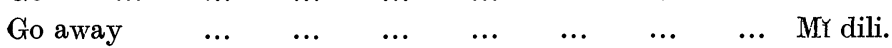

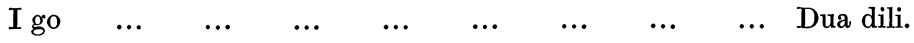

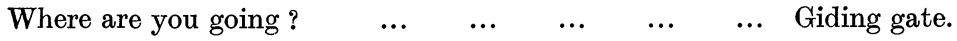

$\begin{array}{llllllll}\text { Go and lie down } & \ldots & \ldots & \ldots & \ldots & \ldots & \ldots & \text { Dili a nei. }\end{array}$

We want to go $\quad \ldots \quad \ldots \quad \ldots \quad \ldots \quad \ldots \quad \ldots \quad$ Gizi a mu dili-(to-morrow).

\section{VERB “To WANT."}

I want food

$\begin{array}{llllll}\ldots & \ldots & \ldots & \ldots & \ldots & \text { Wu sun tilengu. } \\ \ldots & \ldots & \ldots & \ldots & \ldots & \text { Okse yeshi. } \\ \ldots & \ldots & \ldots & \ldots & \ldots & \text { Wula wusun tilengu. } \\ \ldots & \ldots & \ldots & \ldots & \ldots & \text { Kukse mūna. } \\ \ldots & \ldots & \ldots & \ldots & \ldots & \text { Zum tilengu ka. } \\ \ldots & \ldots & \ldots & \ldots & \ldots & \text { Gizi a mu dili-(to-morrow) } . \\ \ldots & \ldots & \ldots & \ldots & \ldots & \text { Bolo sa um tilenkiri. }\end{array}$


What is your name

This cloth is mine

This cloth is Momo's

Dikwa is far ... ...

Dikwa is far $\quad . . \quad$... ...

This is a strong man

This man is not strong

This thing is big

This thing is small

That is a big town

The water in the well is not sweet

This is mine

Give (me)

The woman gave me many eggs.$\quad \ldots \quad \ldots \quad \ldots \quad \ldots \quad \ldots$ Ginum na bare yeshi na kadagu.

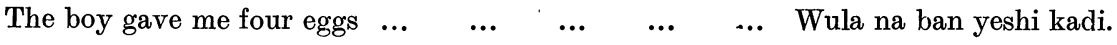

Verb “To SEe."

I see him

I do not see $\mathrm{him} \quad \cdots \quad \cdots$

I saw the woman yesterday ..
VERB “TO BE."

$\begin{array}{lllll}\ldots & \ldots & \ldots & \ldots & \text { Yekó simsá. } \\ \ldots & \ldots & \ldots & \ldots & \text { Luku sa ntu. } \\ \ldots & \ldots & \ldots & \ldots & \text { Luku sa Mamang. } \\ \ldots & \ldots & \ldots & \ldots & \text { Dikwa zigili. } \\ \ldots & \ldots & \ldots & \ldots & \text { Bolosa kakagaseng. } \\ \ldots & \ldots & \ldots & \ldots & \text { Bolosa kakagaseng wa. } \\ \ldots & \ldots & \ldots & \ldots & \text { Manta na dima. } \\ \ldots & \ldots & \ldots & \ldots & \text { Manta na cha. } \\ \ldots & \ldots & \ldots & \ldots & \text { Wuta wuta dima (?). } \\ \ldots & \ldots & \ldots & \ldots & \text { Um di tili wa } \\ & & & & \text { (? “in the well " omitted). } \\ \ldots & \ldots & \ldots & \ldots & \text { Aguntu. }\end{array}$

Verb “To Give."

$$
\begin{array}{lllll}
\ldots & \ldots & \ldots & \ldots & \text { Dua ndali. } \\
\ldots & \ldots & \ldots & \ldots & \text { Dua ndal'ua. } \\
\ldots & \ldots & \ldots & \ldots & \text { Ginum dibela wa ndali. }
\end{array}
$$

\section{Sundry Phrases.}

Open the door ...

$\begin{array}{lllll}\ldots & \ldots & \ldots & \ldots & \text { Jaga za lei. } \\ \ldots & \ldots & \ldots & \ldots & \text { Zia. } \\ \ldots & \ldots & \ldots & \ldots & \text { Zia dale }(\text { ? = dile). } \\ \ldots & \ldots & \ldots & \ldots & \text { Zia zi vun. } \\ \ldots & \ldots & \ldots & \ldots & \text { Zo wa gala. } \\ \ldots & \ldots & \ldots & \ldots & \text { Do. } \\ \ldots & \ldots & \ldots & \ldots & \text { Do am. } \\ \ldots & \ldots & \ldots & \ldots & \text { Moi sikomar. } \\ \ldots & \ldots & \ldots & \ldots & \text { Wa shinga. } \\ \ldots & \ldots & \ldots & \ldots & \text { Wa shinga wa. } \\ \ldots & \ldots & \ldots & \ldots & \text { Wu sung. } \\ \ldots & \ldots & \ldots & \ldots & \text { Wu sung wa. } \\ \ldots & \ldots & \ldots & \ldots & \text { Wa se. } \\ \ldots & \ldots & \ldots & \ldots & \text { Wa zum. } \\ \ldots & \ldots & \ldots & \ldots & \text { Wu ne. } \\ \ldots & \ldots & \ldots & \ldots & \text { Zartūng. } \\ \ldots & \ldots & \ldots & \ldots & \text { Giri. } \\ \ldots & \ldots & \ldots & \ldots & \text { Ka ga zi. }\end{array}$

Take (it)

Take it away ...

Put it in the hut

I have broken the stick

Bring ..

Bring water

Wait a little

I hear .

I do not hear

I know ...

I do not know..

I drink ..

I sleep ...

Sit down

Tell him

Good morning ...

$$
\begin{array}{ccc}
\ldots & \ldots & \ldots \\
\ldots & \ldots & \ldots \\
\ldots & \ldots & \ldots \\
\ldots & \ldots & \ldots \\
\ldots & \ldots & \ldots \\
\ldots & \ldots & \ldots \\
\ldots & \ldots & \ldots \\
\ldots & \ldots & \ldots \\
\ldots & \ldots & \ldots \\
\ldots & \ldots & \ldots \\
\ldots & \ldots & \ldots \\
\ldots & \ldots & \ldots \\
\ldots & \ldots & \ldots \\
\ldots & \ldots & \ldots \\
\ldots & \ldots & \ldots \\
\ldots & \ldots & \ldots \\
\ldots & \ldots & \ldots
\end{array}
$$

When Shehu Lamino came to see Miriama at Ngala she was asleep. Her attendants woke her up and said :-
Agza na lo (=lu)
Mundadi na lo $(=\mathrm{lu})$
Agbwale na lo $(=\mathrm{lu})$...
$\begin{array}{llll}\ldots & \ldots & \ldots & \ldots \\ \ldots & \ldots & \ldots & \ldots \\ \ldots & \ldots & \ldots & \ldots\end{array}$
... Your man with the teeth has come.
... The red man has come.
... The monkey has come.

Shehu Lamino, not understanding, wrote them down for future inquiry.

This was told me a.t Ngala. 
Genitive Case Construction.

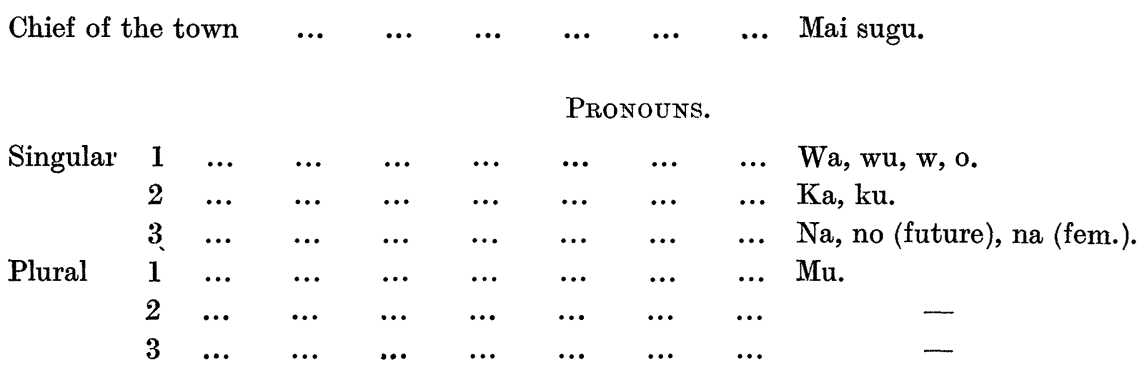

\section{NOTE.}

There are some differences between Barth's verson and mine which I should mention.

Where I have " $\mathrm{N}$ " he may have " $\mathrm{L}$," but this is a recognized phonetic change in many African Janguages.

Again, where I have "Șh" he has "Th." Now Barth was German, and although his knowledge of English was very good, it is open to debate as to how he heard, or rather said, "Th" himself. On the other hand. my informants were very old men, and may have been unable any longer to say "Th."

Barth has for the numerals " 6 " and " 7," Kanuri words in place of the pure Ngala words which I recorded.

As to accent, I sometimes found the last syllable of a word had an emphasis on it, and it was in a rising tone.

I cannot help thinking that in Barth's verson as printed in the late P. A. Benton's book, the letter " $\mathrm{H}$ " has been frequently printed for " $\mathrm{A}$." This is noticeable in the numerals, which read singularly harshly in his version. The error, if such it be, is probably due to Benton's having written the words in block letters, in which case they could easily have been confused in the manuscript. 